\title{
HEAT RESISTANCE OF Bacillus spp. SPORES ISOLATED FROM COW'S MILK AND FARM ENVIRONMENT
}

\author{
B. JANŠTOVÁ, J. LUKÁŠOVÁ \\ Department of Hygiene and Technology of Milk, Faculty of Veterinary Hygiene and Ecology, \\ University of Veterinary and Pharmaceutical Sciences, Brno, Czech Republic \\ Received November 21, 2000 \\ Accepted May 28, 2001 \\ Abstract \\ Janštová B., J. Lukášová: Heat Resistance of Bacillus spp. Spores Isolated from Cow's Milk \\ and Farm Environment. Acta Vet. Brno 2001, 70: 179-184. \\ The aim of this study was to compare heat resistance of the spores of mesophile Bacillus spp. \\ from raw milk (bulk tank milk and milk from individual cows) and farm environment (faeces, \\ silage, litter, swabs from skin and udder) as related to their survival in heat- treated dairy products. \\ Fifty-eight strains of 9 species of Bacillus were tested for termoresistance within the temperature \\ range of $95-135{ }^{\circ} \mathrm{C}$ and various exposure times. The highest termoresistance was found in \\ $B$. licheniformis spores, which survived the temperature of $135{ }^{\circ} \mathrm{C}$. Except for the spores \\ $B$. coagulans and $B$. pumilus all remaining spores were able to germinate after heat treatment of up \\ to $120^{\circ} \mathrm{C}$. The greatest reduction of the spore numbers was found in B. cereus. The results indicate \\ that some Bacillus spores may survive in milk even after heat treatment. \\ Bacillus spp., raw milk, faeces, silage, litter, swabs from skin and udder, spores, termoresistance
}

Aerobic and facultative anaerobic spore-forming bacteria of the genus Bacillus present a serious problem in milk industry. Because of the heat resistance of spores and ability of vegetative cells to produce extra-cellular enzymes they may cause milk and milk product deterioration. Bacillus spp. are quite common in the agricultural environment and may contaminate milk from various sources both during the production, storage and processing. Raw milk is most frequently contaminated under conditions of inadequate udder hygiene, from soil, feed, dust and faeces (Christiansson et al. 1999). Species such as B. licheniformis, B. subtilis and B. cereus (Crielly et al.1994; Páčová et al. 1996) are most commonly isolated from raw milk. B. licheniformis together with $B$. subtilis and $B$. pumilus belong to mesophiles, whereas $B$. cereus is rather a psychrophile able to grow in milk and milk products at cold-storage temperatures and even cause alimentary diseases (Christiansson 1992). It is known that the spores of bacilli survive pasteurisation and have suitable conditions for germination created in the pasteurised milk. B. cereus is a predominating micro-organism influencing the maintenance of pasteurised milk. It causes sweet curdling of milk and changes to milk odour and taste due to the production of the enzymes proteinase, lipase and phospholipase (Meer et al. 1991). Sterilisation and UHT milk treatment are the most effective means of spore destruction showing $99.99 \%$ success (Cox 1974).

Heat resistance is an important character of Bacillus spp. spores. Appropriate temperature selection and duration of heating are crucial for the required microbial quality of the milk product, as with a linear temperature increase the time needed to achieve nearly complete abiosis becomes shorter exponentially. When determining the heat resistance and thus the sufficient duration of thermic treatment, it is useful to define the $\mathrm{D}$ value (decimal reduction time), i.e., a temperature value resulting in a decrease of the number of live microorganisms by one order (Kyzlink 1980 ).

Address for correspondence:

MVDr.Bohumíra Janštová

and Pharmaceutical Sciences Brno

61242 Brno,

Phone: +420 541562607

http://www.vfu.b@ post.cz 
This study deals with heat resistance of spores of bacilli occurring in raw milk and farm environment with regard to the pasteurisation and sterilisation temperatures.

\section{Materials and Methods}

Preparation of spore suspension

The examined strains were spread on the surface of Nutrient agar and incubated $24 \mathrm{~h}$ at $37{ }^{\circ} \mathrm{C}$. The microorganisms were then transferred to $50 \mathrm{ml}$ of peptone water and incubated at $37^{\circ} \mathrm{C}$ for $14 \mathrm{~d}$ and then heated at $80{ }^{\circ} \mathrm{C}$ for $10 \mathrm{~min}$ in order to kill vegetative cells. Sporulation was checked microscopically. The spore content was between $10^{4}-10^{7} \mathrm{ml}^{-1}$. The spore suspensions were stored at $4{ }^{\circ} \mathrm{C}$ until processed.

Thermo-inactivation experiments

A. Determination of thermal resistance of spores

The following 58 strains of the Bacillus genus were selected for the experiments: 21 strains of B. licheniformis, 18 strains of $B$. subtilis, 6 strains of B. cereus, 5 strains of B. sphaericus, 3 strains of $B$. megaterium, 2 strains of B. alvei and 1 strain of $B$. amylolyticus, B. coagulans, B. pumilus. These strains were isolated from bulk milk tanks and individual samples of milk and agricultural environment. The suspension of spores of the given strain, characterised by the number of spores per $1 \mathrm{ml}$ counted by plating on PCA, was diluted before the experiment 1:10 using UHT half-fat milk that was pasteurised at $85^{\circ} \mathrm{C}$ for $10 \mathrm{~min}$ in the laboratory. The volume of $0.5 \mathrm{ml}$ of this initial milk suspension was pre-treated by heating to $75^{\circ} \mathrm{C}$ and then, contained in thin-walled capillaries, subjected to temperatures of $95,100{ }^{\circ} \mathrm{C}$ and $105,110,115,120,135^{\circ} \mathrm{C}$ in water and glycerol baths, respectively. Periods of exposure were selected according to the temperature used. Initial concentrations of spores in suspensions varied from $10^{4}$ to $10^{7} \cdot \mathrm{ml}^{-1}$. After cooling we determined the number of surviving spores using the Plate Count Agar (PCA). We determined D values for all temperatures used and periods of exposure as well as means specific for each Bacillus species. Thermo-inactivation curves were also plotted.

B. Resuscitation of spores

The possibility of resuscitation of microorganisms was checked in 3 strains of B. cereus, B. subtilis, and B. licheniformis. Samples were processed in the same way as in the experiment to determine the thermo-resistance (cf. A). The initial concentration of spores in each strain examined amounted to $10^{1}-10^{5} \cdot \mathrm{ml}^{-1}$ and temperatures of $100,110,120$ and $135^{\circ} \mathrm{C}$ were used for inactivation. The experiment, including a transfer of $0.1 \mathrm{ml}$ of a sample into $0.9 \mathrm{ml}$ of peptone water for the purpose of resuscitation, was performed in duplicate. The first set of samples was plated immediately after the thermal treatment and cooling, while the other one was kept in a refrigerator and the corresponding samples used only in those cases when there was no growth on the PCA detected during the first phase of the experiment. After $24 \mathrm{~h}$ of incubation at $37^{\circ} \mathrm{C}$ we determined the number of spores germinating on the PCA, recounted the value per $1 \mathrm{ml}$ and made a plot.

C. Spore survival dynamics

Samples were processed as in the above-mentioned experiments. The initial concentration used in strains of all 9 species amounted to $10^{4}-10^{5} \cdot \mathrm{ml}^{-1}$. Periods of heating at the temperatures of 95 and $100{ }^{\circ} \mathrm{C} ; 105,110,115$ and $120^{\circ} \mathrm{C}$; and $135^{\circ} \mathrm{C}$ lasted for $1,2,3,4,5 \mathrm{~min} ; 5,10,20,30,60 \mathrm{~s}$; and $5 \mathrm{~s}$, respectively.

Results were evaluated as the number of surviving microorganisms per $1 \mathrm{ml}$ expressed in $\%$.

\section{Results and Discussion}

A total of 58 strains of 9 species of the genus Bacillus were examined, i.e., 21 strains of $B$. licheniformis, 18 strains of B. subtilis, 6 strains of B. cereus, 5 strains of $B$. sphaericus, 3 strains of B. megaterium, 2 strains of $B$. alvei and 1 strain of $B$. amylolyticus, $B$. coagulans,

B. pumilus. The number of strains of individual species examined was influenced by their incidence in raw milk and agricultural environment. Heat resistance of spores was evaluated using the D-value. Mean, minimal and

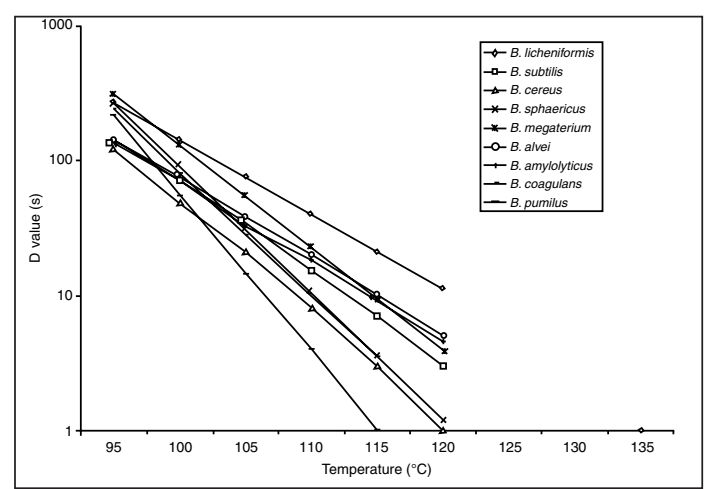

Fig. 1. Thermal death time curves of Bacillus spp. spores 
Table 1

Heat resistance of Bacillus spp. spores

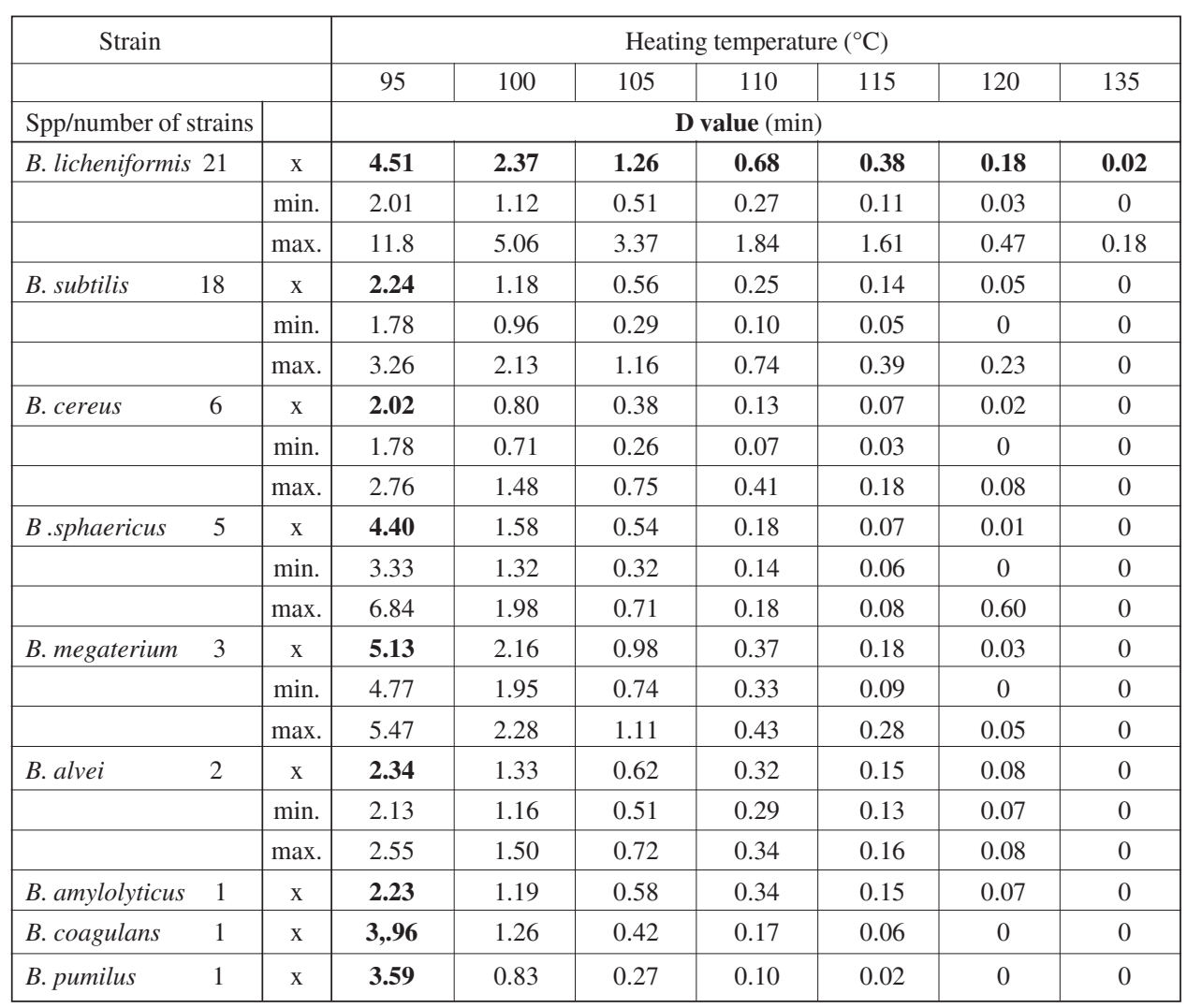

maximal D-values are presented in Table 1. D-values determined and thermo-inactivation curves plotted (Fig. 1) show differences in the speed of inactivation, great variability of spore resistance of individual species as well as individual strains of the Bacillus genus at temperatures examined. The rise of temperatures from 95 to $135{ }^{\circ} \mathrm{C}$ resulted in a continual decrease of the D-value of spores of all species of the Bacillus genus. Fig. 1 clearly shows that the temperature of $135^{\circ} \mathrm{C}$ is adequate for the inactivation of spores even in high initial concentrations (up to $10^{7}$. $\mathrm{ml}^{-1}$ ) of all strains studied except for $B$. licheniformis, spores of which were on exception able to germinate even after heating to this temperature. The temperature which spores of all strains studied remained active at was $115{ }^{\circ} \mathrm{C}$. The temperature of $120^{\circ} \mathrm{C}$ was survived by spores of B. licheniformis, B. subtilis, B. cereus, B. sphaericus, B. megaterium, B. alvei and B. amylolyticus. Spores of B. coagulans and $B$. pumilus were not able to germinate at this temperature.

$B$. licheniformis showed the greatest heat resistance as compared to other species examined. The respective $\mathrm{D}$ values at temperatures of $95,100,105,110,115,120$ and $135{ }^{\circ} \mathrm{C}$ amounted to $4.51,2.37,1.26,0.68,0.38,0.18$ and $0.02 \mathrm{~min}$. There was also the greatest heat-resistance variability of strains in this species. Our results are in good agreement with data of Pendurkar et al. (1989). The revival of germination of spores that were only sub-lethally impaired (i.e., resuscitation) was found in 18 cases out of 42 (i.e., $42.9 \%$ ) experiments at temperatures up to $120{ }^{\circ} \mathrm{C}$. There was no resuscitation found at the 
temperature of $135{ }^{\circ} \mathrm{C}$. The success rate of spore resuscitation of individual species at temperatures of 100,110, 120 and $135^{\circ} \mathrm{C}$ can be seen in Fig. 2. Table 2, presenting the spore destruction dynamics, shows again greater resistance of $B$. licheniformis spores in comparison with other species.

The second most commonly isolated species from milk and agricultural environment, i.e. B. subtilis (Páčová et al. 1996), was more susceptible to the temperatures used than $B$. licheniformis. The D value at $95^{\circ} \mathrm{C}$ was $2.24 \mathrm{~min}$, similar to the study by Stojanovic et al. (1997). After heating the suspension of spores to $135^{\circ} \mathrm{C}$ we noticed no growth; active spores, however, were found at the temperature of $120^{\circ} \mathrm{C}$. Pendurkar et al. (1989) also mentioned its lower heat resistance.

$B$. cereus species received great attention, the fact being documented by many authors, because it is an important pasteurised milk contaminant. Vegetative cells are devitalised by

Table 2

Effect of different temperature/ time combinations on the surviving of spores B. licheniformis, B. subtilis, B. cereus

\begin{tabular}{|c|c|c|c|c|}
\hline Temperature & Heating time & B. licheniformis & B. subtilis & B. cereus \\
\hline${ }^{\circ} \mathrm{C}$ & $\min$ & $\%$ & $\%$ & $\%$ \\
\hline \multirow{5}{*}{95} & 1 & 47.08 & 35.66 & 31.82 \\
\hline & 2 & 25.03 & 12.96 & 10.16 \\
\hline & 3 & 13.09 & 4.66 & 3.48 \\
\hline & 4 & 8.13 & 1.81 & 1.27 \\
\hline & 5 & 4.97 & 0.69 & 0.38 \\
\hline \multirow[t]{6}{*}{100} & 1 & 51.56 & 13.98 & 8.69 \\
\hline & 2 & 27.88 & 3.00 & 1.22 \\
\hline & 3 & 8.23 & 0.59 & 0.34 \\
\hline & 4 & 4.10 & 0.12 & 0.05 \\
\hline & 5 & 1.81 & 0.03 & 0.01 \\
\hline & Sec. & & & \\
\hline \multirow[t]{5}{*}{105} & 5 & 80.05 & 67.67 & 55.58 \\
\hline & 10 & 64.96 & 46.78 & 34.27 \\
\hline & 20 & 44.49 & 23.69 & 13.62 \\
\hline & 30 & 28.58 & 12.02 & 8.69 \\
\hline & 60 & 11.96 & 2.52 & 1.66 \\
\hline \multirow[t]{5}{*}{110} & 5 & 64.94 & 40.78 & 17.69 \\
\hline & 10 & 45.57 & 20.25 & 6.68 \\
\hline & 20 & 24.12 & 6.42 & 2.43 \\
\hline & 30 & 14.04 & 2.14 & 0.81 \\
\hline & 60 & 3.72 & 0.27 & 0.07 \\
\hline \multirow[t]{5}{*}{115} & 5 & 41.96 & 19.83 & 6.71 \\
\hline & 10 & 22.71 & 6.10 & 1.69 \\
\hline & 20 & 11.41 & 1.23 & 0.13 \\
\hline & 30 & 4.95 & 0.39 & 0.03 \\
\hline & 60 & 0.98 & 0.02 & 0 \\
\hline \multirow[t]{5}{*}{120} & 5 & 21.58 & 5.12 & 0.81 \\
\hline & 10 & 9.27 & 1.44 & 0.13 \\
\hline & 20 & 3.58 & 0.14 & 0 \\
\hline & 30 & 1.75 & 0 & 0 \\
\hline & 60 & 0.29 & 0 & 0 \\
\hline 135 & 5 & 2.33 & 0 & 0 \\
\hline
\end{tabular}




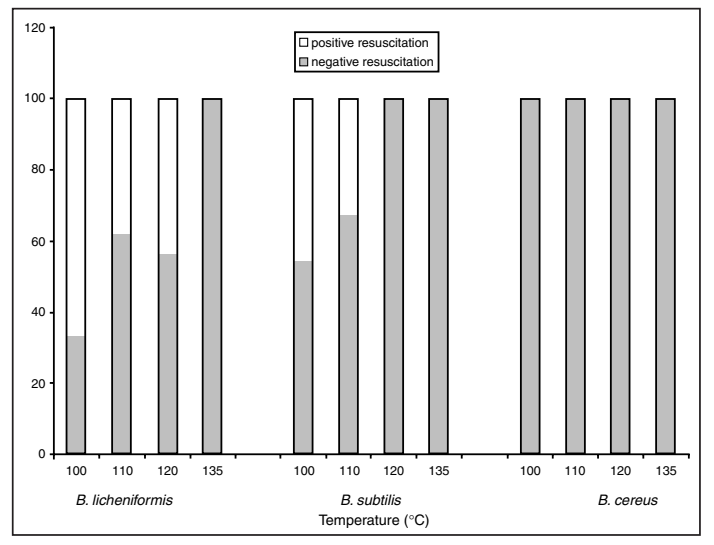

Fig. 2. Recovery of spores B. licheniformis, B. subtilis, B. cereus from heat injury pasteurisation temperatures, the ability of spores to germinate, however, remains unaffected. Spores, nevertheless, mostly do not survive sterilisation temperatures. Out of the six strains examined, only one survived the temperature of $120^{\circ} \mathrm{C}$. The temperature of $135{ }^{\circ} \mathrm{C}$ was sufficient for the destruction of spores. Nagarajan et al. (1990) found that B. cereus spores survived $100{ }^{\circ} \mathrm{C}$ for $10 \mathrm{~min}$ in sterile milk. We, however, did not prove this. Our results, nevertheless, are comparable to those by other authors such as Griffiths et al. (1986). The destruction of spores in dependence on the temperature and time was much quicker as compared to B. subtilis and B. licheniformis (Table 2), while the germination of spores was not revived by resuscitation (Fig. 2).

As far as other species are concerned, we examined a smaller number of strains, because their occurrence in milk samples was low. These findings, therefore, are only complementary. It is clear that, should we examine more numerous samples, there would have been greater variability in heat resistance. The heat destruction of spores in strains of $B$. sphaericus and $B$. megaterium at temperatures up to $100^{\circ} \mathrm{C}$ was slower than in other species, similarly as in the spores of B. licheniformis. Great resistance of B. sphaericus was found by Kamei et al. (1990). We did not confirm the results reporting survival of spores at the temperature of 140 ${ }^{\circ} \mathrm{C}$. Spores of B. coagulans and B. pumilus strains did not survive the temperature of $120{ }^{\circ} \mathrm{C}$.

Mikolajcik (1969) reports the respective D values at 95 and $100{ }^{\circ} \mathrm{C}$ in $B$. pumilus, B. coagulans, B. megaterium and B. sphaericus being 4.03 and $0.875,6.90$ and $1.97,6.50$ and 2.35 , and 7.60 and 2.25 minutes. In B. pumilus, B. coagulans, B. megaterium, and $B$. sphaericus we found at the above-mentioned temperatures the following the respective D values: 3.59 and $0.83,3.96$ and $1.26,5.13$ and 2.16, 4.40 and $1.58 \mathrm{~min}$. The finding of B. amylolyticus in raw milk is interesting. Even when we examined only one strain, it can be stated that its spores may survive the temperature of $120^{\circ} \mathrm{C}$.

Evaluating our results on the heat resistance of species of the Bacillus genus, we may conclude that especially the spores of $B$. licheniformis are able to survive the UHT process. Considering the concentration of spores in raw milk and the dynamics of their destruction during heating, $B$. licheniformis is not much dangerous for the UHT milk quality.

Spores of other bacilli surviving the temperatures from 95 to $120^{\circ} \mathrm{C}$, may play their important role in the contamination of cream and high pasteurised milk for the production of some milk foods.

When evaluating the heat resistance of spores, it is necessary to consider the fact that in the laboratory we cannot create the same environment and conditions for the sporulation as in the natural substrate. We, therefore, have to take into consideration some differences in the heat resistance as compared to spores in the natural environment of foods.

\section{Termorezistence spór mikroorganismů rodu Bacillus izolovaných z mléka a zemědělského prostředí}

Cílem práce bylo porovnání termorezistence spór mezofilních druhů rodu Bacillus vyskytujících se v syrovém mléce ve vztahu k přežívání v tepelně ošetřených mléčných 
výrobcích. U 58 kmenů 9 druhů rodu Bacillus byla stanovena termorezistence spór v UHT mléce v rozsahu teplot $95-135^{\circ} \mathrm{C}$ při různé expozici. Nejvyšší termorezistence byla zjištěna u $B$.licheniformis, jehož spóry přežily teplotu $135^{\circ} \mathrm{C}$. Spóry schopné klíčit byly u ostatních druhů zaznamenány při teplotě $120^{\circ} \mathrm{C}$, s výjimkou $B$. coagulans a $B$. pumilus. Redukce spór byla nejrychlejší u $B$. cereus ve srovnání s $B$ licheniformis a $B$. subtilis. Výsledky poukazují na možnost přeživání některých spór rodu Bacillus v mléce ošetřeném vysokými teplotami.

\section{Acknowledgements}

This study was supported by grant of Ministry of Education, Youth and Sports of the Czech Republic No. 162700005 .

\section{References}

COX, W. A. 1975: Problems associated with bacterial spores in heat- treated milk and dairy products. J. Soc. Dairy Technol. 28: 59-68

CRIELLY, E. M., LOGAN, N. A., ANDERTON, A. 1994: Studies on the Bacillus flora of milk and milk products. J. Appl. Bacteriol. 77: 256-263

GRIFFITHS, M. W., HURVOIS, Y., PHILLIPS, J. D., MUIR, D. D. 1986: Elimination of spore-forming bacteria from double cream using sub-UHT temperatures . Milchwissenschaft 41: 403-405, and 474-478

CHRISTIANSSON, A. 1992: The toxicology of Bacillus cereus. Bull. Int. Dairy Fed. 275: 30-35

CHRISTIANSSON, A., BERTILSSON, J., SVENSSON, B. J. 1999: Bacillus cereus spores in raw milk: Factors affecting the contamination of milk during the grazing period. J. Dairy Sci. 82: 305-314

KAMEI, T., NAKAYAMA, K., SATO, J., NAKAI, Y., NODA, K. 1990: Behavior and heat resistance of Bacillus spp.isolated from raw milk. Brief Communications of the XXIII. International Dairy Congress, Montreal, October 8-12, Vol. I. 58

KYZLINK, V. 1980: Základy konzervace potravin. Praha SNTL, pp. 229-230

MEER, R. R., BAKER, F. W., BODYFELT, F. W., GRIFFITHS, M. W. 1991: Psychrotrophic Bacillus spp. in fluid milk products. A review. J. Food Prot. 54: 969-979

MIKOLAJCIK, E. M. 1970: Thermodestruction of Bacillus spores in milk. J. Milk Food Technol. 33: 77-82

NAGARAJAN, L., SELVAKUMARAN, R., KUMAR, V. U., UMESKUMAR, S., 1990: Deterioration in milk quality due to a psychrotrophic Bacillus cereus during storage at low temperatures. Chem. Microbiol. Technol. der Lebensmittel 12: 168-170

PÁČOVÁ, Z., VYHNÁLKOVÁ, J., LUKÁŠOVÁ, J., HOLEC, J. 1996: Identification of aerobic and facultatively anaerobic sporulating bacteria isolated from operations of milk primary production. Vet. Med. - Czech 41: 1923

PENDURKAR, S. H., KULKARNI, P. R. 1989: Heat resistance of Bacillus spores exposed to food processing conditions. Die Nahrung 34: 177-180

RAJU, V. V, KUMAR, M. K. 1989: Heat resistance of aerobic sporeforming bacteria in milk. The Ind. J. Dairy Sci.. 42: $71-74$

STOJANOVIC, E., MIJAČEVIC, Z., OLJAČIC, E. 1997: The influence of sampling location on the different mikroorganisms in raw milk. Proceedings of the World Congress of Food Hygiene. Haague, Netherlands, 236 p. 